\title{
Entre o prestígio e a penúria: o Museu Paulista e a aquisição de um laboratório fotográfico
}

Between the prestige and the penury: the Paulista Museum and the acquisition of a photographic laboratory

\section{EDUARDO AUGUSTO COSTA'}

Universidade de São Paulo / São Paulo, SP, Brasil

RESUMO: Este artigo busca apresentar a trajetória institucional do Museu Paulista durante a década de 1930, essencialmente na relação com os processos de visibilidade de seus projetos científicos e históricos. A fotografia e os impressos são tratados como pontos centrais desse processo, em que o laboratório fotográfico e a publicação da Revista do Museu Paulista cumprem um papel fundamental para a sua sustentação. Em paralelo, destaca-se a situação orçamentária, que impedia o rápido acesso aos recursos necessários para a manutenção do prestígio internacional. $\bigcirc$ debate se equaciona em torno da cultura visual e da história intelectual da primeira metade do século XX.

PALAVRAS-CHAVE: Cultura visual. Fotografia. Impressos. História intelectual.

ABSTRACT: This study shows the institutional trajectory of the Paulista Museum during the 1930s, essentially in the relation with the visibility processes of its scientific and historical projects. Photography and prints are treated as central points of this process, in which the photographic laboratory and the publication of the Revista do Museu Paulista play a key role in sustaining it. Parallelly, the study focuses on its precarious financial condition, which prevented rapid access to the needed resources to maintain the international prestige. The debate is in between the visual culture and the intellectual history of the first half of the 20th century.

KEYWORDS: Visual culture. Photography. Prints. Intelectual history.

\begin{abstract}
1. Pós-doutor pelo Instituto de Filosofia e Ciências Humanas da Universidade Estadual de Campinas (IFCH-Unicamp), onde também defendeu seu mestrado e doutorado. Graduou-se em arquitetura pela Unicamp e realizou doutorado-sanduíche na Universidade de Coimbra, Portugal (2011-2012). Foi vencedor do XI Prêmio Funarte Marc Ferrez de Fotografia, em 2010, e do ProAC/14 - 2009, da Secretaria de Estado da Cultura do Governo de São Paulo. É pesquisador colaborador do Departamento de História da Arquitetura e Estética do Projeto da Faculdade de Arquitetura e Urbanismo da Universidade de São Paulo (FAU-USP), desde 2018. E-mail: <eduardocosta01@ gmail.com>
\end{abstract}


2. Arquivo do Museu Paulista (1937, p. 26).

3. Arquivo da Prefeitura Municipal de São Paulo (1938, p. 13).

4. Cf. Faria (1994).

5. Cf. Duarte (2007)

\section{INTRODUÇÃO}

Affonso d'Escragnolle Taunay, diretor do Museu Paulista, noticiou a compra de "um laboratório photographico completamente montado e colocado na Secção de Invertebrados" do museu, destacando que "veio este aparelho preencher séria lacuna no nosso Instituto, tendo sido portanto acquisição de real vantagem". ${ }^{2}$ Por si só, a informação da compra de um laboratório fotográfico completo levanta importantes questões quanto à história do Museu Paulista. Para além dessa instituição, o fato projeta questões relativas à cultura brasileira do século XX, salientando que o debate da visualidade era matéria de primeira ordem para a constituição de uma cultura moderna. Se não bastasse a noticiada lacuna, Taunay a adjetiva como "séria", expondo que tal equipamento seria imprescindível ao funcionamento do museu nos anos 1930.

A aquisição desse laboratório merece, no entanto, uma atenção ainda maior quando contraposta a outras ações que foram levadas a cabo no Brasil daquele período. No mesmo mês em que Taunay descreveu tal aquisição, o chefe da subdivisão de documentação social e estatística do município de São Paulo, Bruno Rodolfer, lembrava ao chefe da divisão que o Ato n 1325, de 4 de janeiro de 1938, considerava o cargo de "técnico de iconografia", para o qual destacava o nome de Benedito Junqueira Duarte, indicado "por comprovada competência para as funções referidas". ${ }^{3}$ B. J. Duarte, como ficou conhecido, passava assim a integrar o corpo de funcionários do Departamento de Cultura, onde foi responsável por documentar as atividades culturais promovidas pela capital paulista. A importância da incorporação desse fotógrafo como servidor público pode ser compreendia se contraposta à memória visual que se firmou quanto às ações implementadas pela Prefeitura naquele período. B. J. Duarte foi responsável por documentar as atividades dos Parques Infantis, política implementada pelo Departamento de Cultura a partir de 1935,4 o cotidiano urbano da cidade, assim como as transformações impostas pelos novos edifícios modernos e públicos em processo de construção. Suas fotografias constituíram uma representação de grande permanência e aderência na cultura brasileira. ${ }^{5}$ 
A relação com a organização de uma visualidade capaz de promover os feitos públicos e assim estabelecer uma imagem renovada para a cidade aparece em outras ações da Prefeitura de São Paulo na época. Em 24 de agosto de 1937, mesmo ano em que Taunay comprou o laboratório para o Museu Paulista e alguns meses antes de B. J. Duarte integrar a equipe do Departamento de Cultura, o chefe do Departamento de Educação e Recreio selava um acordo de troca de um aparelho cinematográfico escolar usado e até então pertencente ao Departamento por uma "Machina Photográfica Zeiss-lkon typo Ikoflex mod. II" e um "Estojo de couro para a machina acima". 6 A mudança selada por tal negociação revela um desejo de produzir documentos visuais, a serem divulgados essencialmente através dos suportes impressos - livros, jornais e periódicos - em detrimento da reprodução de material já consolidado em rolos de acetato de 35 milímetros. A produção de imagens representativas do novo espírito social assumia um papel importante na manutenção de um discurso político de transformação. A cultura moderna requeria uma visualidade fotográfica nova e compatível com o discurso de mudança.

A imbricada associação entre o desejo de se estabelecer perante uma cultura moderna e a construção de uma visualidade condizente reaparece em outras importantes ações públicas e culturais no Brasil. Uma delas foi o curso de etnografia e folclore, promovido pelo Departamento de Cultura da Prefeitura de São Paulo no ano de 1936, um ano antes de Taunay adquirir o equipamento para - Museu Paulista. Ministrado por Dina Dreyfus, etnógrafa que viera ao Brasil ao lado de outros franceses para ministrar disciplinas na Universidade de São Paulo (USP), criada em 1934, o curso de etnografia e folclore foi fundamental para que um saber científico e moderno - europeu e ocidental - pudesse ser apropriado pela cultura brasileira, incorporando-se, para tanto, padrões científicos de documentação fotográfica. ${ }^{7}$ Tais procedimentos acabaram por ter impacto não apenas na produção etnográfica brasileira, mas também em outras áreas científicas.

Não por menos, foi um dos alunos do curso, o arquiteto Luis Saia, o responsável pela documentação visual da Missão de Pesquisas Folclóricas organizada por Mário de Andrade, também no ano de 1936. Nessa documentação vê-se não apenas a preocupação por representar de maneira clara a arquitetura do Nordeste - onde volumetrias, texturas e materiais aparecem destacados por uma boa escolha de luzes, posicionamento de câmera, representação espacial e outros aspectos -, mas também manifestações artísticas, apresentadas em detalhes por séries fotográficas realizadas com rigor e metodologia difundidos por Dreyfus no curso de etnografia e folclore. Se a fotografia ocupou um lugar importante na propaganda das novas agendas sociais da cidade de São Paulo, ela também imputava relevância científica à instituição que dela se utilizasse. Sua divulgação
6. Arquivo da Prefeitura Municipal de São Paulo (1937, p. 3).

7. Cf. Carlini (1994). 
8. Cf. Mauad (2016).

9. Cf. Caraffa (2011).

10. Andrade (1981).

11. Cf. Lissovsky; Jaguaribe. extrapolava os interesses de promoção de políticas públicas; tratava-se também de um meio de validação e comprovação de seriedade e compromisso com a ciência. ${ }^{8}$ Esse compromisso ou objetivo não se restringiu ao Brasil, mas integrava um movimento mais amplo, iniciado no final do século XIX e com grande repercussão institucional nas primeiras décadas do século XX, em que a fotografia funcionava como cartão de visitas do compromisso científico das instituições. Tratava-se, portanto, de instrumento inerente à legitimação institucional. ${ }^{9}$

Instituto do Patrimônio Histórico e Artístico Nacional (Iphan), não por menos, nasceu e se firmou enquanto instituição respeitável nacional e internacionalmente através de uma imbricada associação com os documentos fotográficos. Sob essa perspectiva, Rodrigo Mello Franco de Andrade e Mário de Andrade debateram exaustivamente, desde a elaboração do anteprojeto do instituto, o tema da fotografia e sua relação com atividades ligadas à preservação e ao tombamento de bens patrimoniais. ${ }^{10}$ Processos de tombamento, relatórios científicos, cadernos de obras, volumes de sua revista e um infindável número de outros suportes revelam a importância da fotografia no Iphan, um ano antes de Taunay comprar o equipamento fotográfico para o Museu Paulista. Nesse contexto, o arquiteto Luis Saia, aluno do curso de etnografia do Departamento de Cultura e membro da Missão de Pesquisas Folclóricas, foi designado ao cargo de arquiteto da Superintendência do Iphan em São Paulo, no ano de 1937, sendo especialmente atuante no controle e debate da visualidade pretendida pelo instituto. Os saberes visuais e científicos apreendidos em uma instituição transitavam por outras, através de seus fotógrafos, arquitetos, antropólogos, historiadores e demais profissionais. Em formação, a visualidade do Estado-Nação, do Brasil de Getúlio Vargas, percorria as entranhas institucionais, firmando-se como potente discurso. ${ }^{11}$

A compra de um laboratório equipado não foi, portanto, um ato isolado e independente do Museu Paulista ou mesmo de seu diretor, mas respondeu a um contexto mais amplo e indissociável do documento fotográfico. Tal compreensão aparece indiretamente na carta endereçada por Taunay a Candido de Moura Campos, no dia 20 de maio de 1937. Nesse documento o diretor relata:

Necessitando o Museu Paulista de um laboratório photographico para os trabalhos das secções, o que lhe faz enorme falta, não se compreendendo mesmo que um estabelecimento como este esteja desaparelhado de recursos photographicos, e obrigado a recorrer a photographos de fora, com o que despende bastante anualmente e perda de tempo, resolveu esta diretoria montar um gabinete fotográfico. 
Para o diretor do Museu Paulista, o gabinete fotográfico respondia a uma necessidade urgente de um museu "como este". Substituía-se, assim, as frequentes contratações de fotógrafos freelancer - prática recorrente em instituições públicas do período - por um equipamento permanente e à disposição dos funcionários. Tal investimento institucional em fotografia ganha contornos ainda mais sólidos ao se identificar que, em 23 de setembro de 1938, poucos meses após a compra do laboratório fotográfico, o Museu Paulista requereu uma "máquina fotográfica Graflex" para os trabalhos de campo. ${ }^{12}$ Os naturalistas responsáveis pelas incursões científicas no interior do estado ganhavam um novo equipamento, que facilitaria a documentação de sua rotina de viagem, assim como de suas descobertas. Era de papel, lápis e câmara clara que os naturalistas do Museu Paulista podiam se munir nas missões pelo interior do país até a compra do equipamento fotográfico, o que representava falta grave à rotina científica da instituição e compunha requisições desde o início dos anos 1930.

A primeira manifestação de Taunay quanto à necessidade institucional de equipamentos e profissionais ligados à fotografia data de janeiro de 1932. Ao escrever o relatório anual do exercício de 1931, Taunay ressaltava ao secretário que: "O museu precisaria muito de um photógrafo fixo que ao mesmo tempo fosse desenhista". ${ }^{13}$ Tal manifestação perdura ao longo de toda a década de 1930, sendo repetidamente destacada nos relatórios e também em cartas encaminhadas a um grande número de autoridades. Como anotado por Taunay no ano de 1937, tratava-se de "anomalia absolutamente extraordinária num instituto de sua natureza". ${ }^{14}$ A mudança na política de produção de imagens respondia a uma dinâmica internacional, à qual o Museu Paulista esteve plenamente integrado nos anos anteriores. A relação com instituições museológicas e científicas garantia uma posição privilegiada e prestigiosa, o que rendia importantes solicitações internacionais, como o convite para participar da Conferência Internacional de Atenas sobre o Restauro dos Monumentos - realizada em 1931 e responsável pela elaboração da Carta de Atenas ${ }^{15}$-, convite este que Taunay recusou por falta de recursos financeiros. ${ }^{16}$ Tal relação, ao mesmo tempo que sustentava uma posição internacional relevante, pressionava o Museu Paulista a adotar procedimentos compatíveis com o que vinha sendo praticado por instituições congêneres.

A produção de imagens bem definidas, padronizadas e assimiláveis pela comunidade científica era assunto de primeira ordem para a sobrevivência das instituições museológicas, o que vinha sendo debatido desde o final do século XIX pelos historiadores da arte e que, por isso, merece uma breve sinalização. ${ }^{17}$ A compra do laboratório fotográfico pelo Museu Paulista não representa, portanto, apenas uma importante etapa de modernização, mas um movimento imprescindível para fazer frente a outras instituições e, assim, manter o prestígio e o reconhecimento internacional desse museu.
12. Carta de Taunay a Alvaro de Figueiredo Guião, secretário da Educação e Saúde Pública (23 set. 1938).

13. Arquivo do Museu Paulista (1931, p. 4).

14. Arquivo do Museu Paulista (1933, p. 39).

15. Cf. Cury (2004).

16. Carta de Taunay ao diretor da The American Association of Museums, em Washington (23 jul. 1931).

17. Cf. Wölfflin (2013). 
18. Cf. Oliveira (2017).

19. Taunay relata a oferta em carta encaminhada em 24 de abril de 1937 ao alemão Paulo (sic) Stille.

\section{UMA REDE DE FOTÓGRAFOS E OS DIVERSOS USOS DA FOTOGRAFIA}

A gestão de Affonso d'Escragnolle Taunay, à frente do Museu Paulista entre 1917 e 1945, possui uma aproximação muito ajustada em relação aos documentos fotográficos. ${ }^{18}$ Tais documentos cumpriram um papel importante para assimilação dos avanços científicos, especialmente no campo da zoologia. Mas foram também fundamentais na organização de um referencial visual que serviria de base para elaboração de uma narrativa histórica primorosamente engendrada por Taunay. Retratos de figuras públicas e heróis nacionais, reprodução de telas representativas de passagens e feitos históricos, paisagens e cenas urbanas, além de diversos outros elementos visuais organizavam um referencial de alto valor para a composição de representações encomendadas pelo Museu Paulista. $\bigcirc$ lugar ocupado pela fotografia era, portanto, primordial para o funcionamento da instituição, o que tornava crucial o estabelecimento de uma rede de fotógrafos capaz de atender às necessidades cotidianas.

Em carta de 20 de maio de 1931, Taunay recomendava os serviços do fotógrafo Quinto Lazzarini ao advogado e amigo dr. Djalma Forjaz, indicando que o profissional trabalhava para o museu a dez anos, "servindo sempre com muita solicitude e seriedade, além de ser um excelente profissional". Taunay destaca ainda que "o Sr. Quinto Lazzarini é muito razoável em seus preços". A recomendação dos serviços de Lazzarini revela um laço duradouro entre o fotógrafo e o museu, que perdurava desde o início da década de 1920. Lazzarini foi recorrentemente solicitado por Taunay para os mais diversos serviços fotográficos, exercendo a função de fotógrafo freelancer e, assim, atendendo às eventuais demandas da instituição. Há, portanto, certa correspondência ou aproximação entre as atividades exercidas por Taunay na direção do museu e a atuação desse fotógrafo, pelo menos até meados dos anos 1930. Ao lado de Quinto Lazzarini, o fotógrafo Frederico Egner exerceu funções semelhantes, mas atendendo às demandas do Museu Republicano, sediado na cidade de ltu.

A documentação arquivada pelo Museu Paulista sugere que foram estes os profissionais mais solicitados pela Seção de História da instituição no decorrer das décadas de 1920 e 1930, indicando certa constância nas necessidades de serviços fotográficos, o que também requeria um mínimo controle da documentação. Tratava-se da estabilidade de uma visualidade já assimilada ou autorizada. Nesse sentido, Taunay qualifica Lazzarini como um "excelente profissional", destacando 
que a longeva parceria era fruto de respostas positivas fornecidas pelo fotógrafo. Mas vale também destacar que os preços razoáveis praticados facilitavam sua contratação com os parcos recursos disponíveis. A penúria orçamentária associada à necessidade de manter certa notoriedade institucional, certificada por bons documentos fotográficos, pressionava a rotina de serviço público do Museu Paulista. Apesar do desejo de obter arquivos ou séries fotográficas, foram raras essas compras, que despendiam grandes cifras de um limitado orçamento público. $\bigcirc$ Museu Paulista não podia se dar ao luxo de tal empreitada, e empregava recursos apenas em questões indispensáveis ao seu funcionamento e compatíveis com sua política. No entanto, algumas ações dessa natureza acabaram por se efetivar, fruto de parcerias ou iniciativas articuladas, em muitas ocasiões, pelos próprios fotógrafos.

Uma pequena aquisição demonstra o lugar ocupado pelo museu perante uma rede de fotógrafos e também entre uma intelectualidade brasileira do início do século XX: cinco fotografias de autoria de Paul Stille. Fotógrafo alemão radicado no Brasil, Stille mantinha estúdio no Rio de Janeiro, então capital federal, o que the favorecia a documentação de significativos conjuntos edificados, assim como o acesso a possíveis compradores e o deslocamento para outras regiões do país. Em 1937, mesmo ano em que o Museu Paulista adquiriu o laboratório fotográfico, Stille ofertou à instituição cinco fotografias de edifícios icônicos para a história do país: ${ }^{19} \bigcirc$ Convento de São Francisco, em Olinda; a Igreja da Ordem Terceira de São Francisco, em Salvador; a Igreja de São Bento, no Rio de Janeiro; a Fazenda do Paraíso, no sul de Minas; e uma estátua de profeta de autoria de Aleijadinho, em Congonhas do Campo, foram os temas retratados nas cinco fotografias ofertadas ao museu. ${ }^{20}$

Esse pequeno conjunto de fotografias enfatizava a narrativa do Nordeste açucareiro, do ciclo do ouro nas Minas Gerais e do Rio de Janeiro capital federal, ainda que mereça destaque a presença do sul de Minas, sugerindo uma narrativa em torno do Sudeste cafeeiro. Vale também ressaltar que a aceitação dessas fotografias por Taunay não se deve a uma eventualidade ou apenas ao desejo de aumentar a coleção do museu. As fotografias encaminhadas por Stille trazem registros muito bem ajustados à boa qualidade necessária às instituições. $\bigcirc$ interior da lgreja de São Bento no Rio de Janeiro (Figura 1) deixa claro o uso qualificado desses recursos, indicando o emprego de tripé e câmera de grande formato com báscula, capaz de produzir um registro onde as linhas verticais permanecem paralelas, além de suavizar luzes e sombras, dando clareza de leitura para os rocailles da talha barroca. 
21. Cf. Rubino (1991).

22. Carta de Taunay a Rodrigo Mello Franco de Andrade (7 fev. 1934). Freyre (1933).

23. Carta de Taunay a Sergio Buarque de Holanda (17 nov. 1936). Holanda (1936).

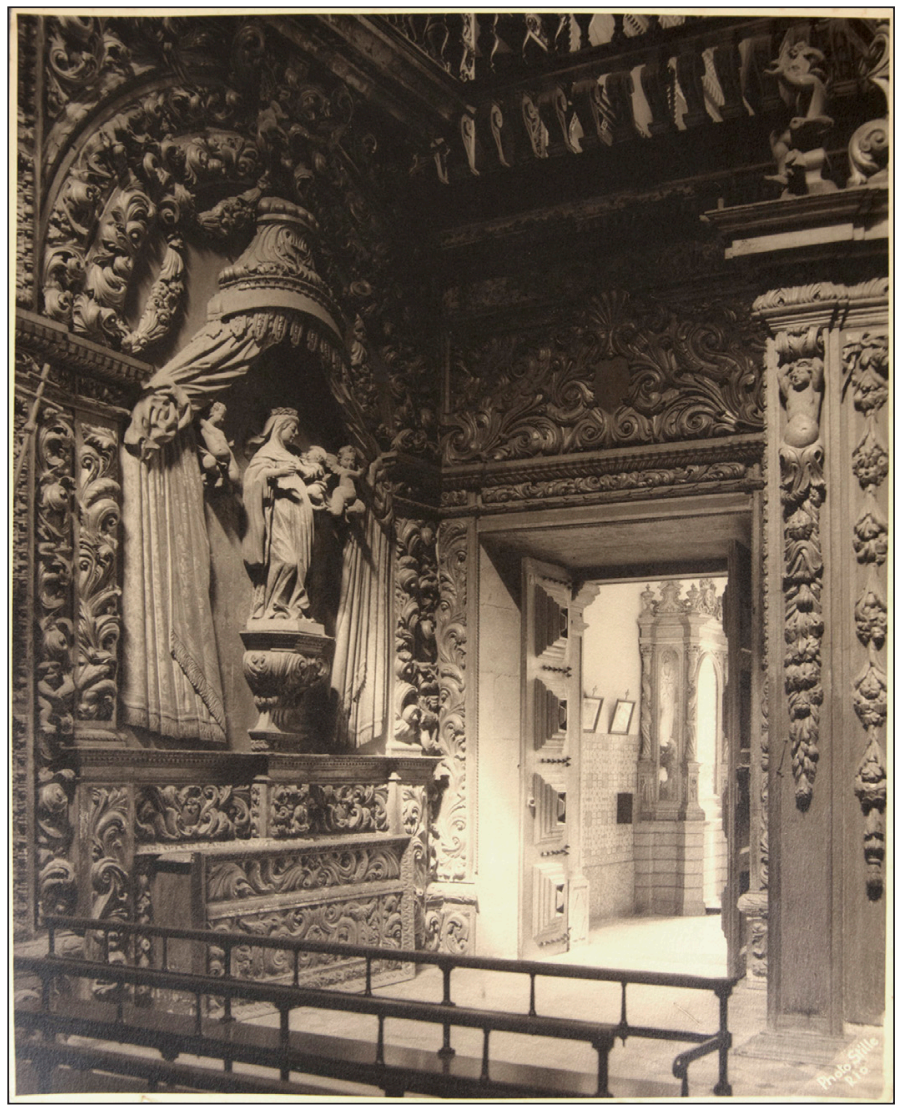

Figura 1 - Interior da Igreja de São Bento no Rio de Janeiro. Fotógrafo: Paul Stille. Fonte: Arquivo do Museu Paulista, s/d.

Os documentos ofertados por Stille não eram despretensiosos e cumpriam os requisitos científicos desejados por instituições do porte e da relevância do Museu Paulista.

A narrativa apresentada por Stille não surpreende em vista da grande circulação que o fotógrafo ostentou no decorrer do governo de Getúlio Vargas, responsável em grande parte pela difusão e construção de uma memória heroica dos ciclos socioeconômicos e políticos do Brasil. ${ }^{21}$ Também não surpreende sua recepção pelo Museu Paulista, sabendo-se das relações intelectuais que Taunay mantinha com outros pensadores, como Rodrigo Mello Franco de Andrade, a quem agradece o envio do livro Casa Grande e Senzala de Gilberto Freyre, ${ }^{22}$ e Sergio Buarque de Holanda, que presenteara Taunay em 1936 com um exemplar de Raízes do Brasil. ${ }^{23}$ A narrativa oficial, muito difundida entre a intelectualidade alinhada ao governo de Vargas, era acompanhada por Taunay no Museu Paulista. 
Ainda que seu projeto fosse divergente em diversos aspectos, não podia deixar de acompanhar a produção intelectual recente, assim como os novos intelectuais brasileiros prescindiam do diálogo com o diretor do Museu Paulista. Nesse aspecto, a incorporação das fotografias de Stille ganha contornos mais claros, especialmente pela relação do fotógrafo com empreendimentos importantes do período, como a Obra Getuliana - projeto visual representativo dos feitos do governo de Getúlio Vargas, com evidente intuito publicitário e comemorativo da política varguista, mas que não chegou a se efetivar ${ }^{24}$ - e o livro Brazil Builds, editado pelo Museu de Arte Moderna de Nova York e cuja elaboração teve grande participação do Iphan. ${ }^{25}$

A aproximação de Paul Stille com o Museu Paulista revela, portanto, a relevância institucional que o museu possuía no cenário nacional. Sabendo da importância dos documentos visuais apresentados pelo fotógrafo, que trazia "magníficas photographias", Taunay recorre ao "Diretor da Faculdade de Sciencias e Letras" da recém-criada USP, que o autoriza a comprar algumas fotografias estimadas em até "um conto e quinhentos" réis. ${ }^{26}$ Não tendo à disposição os recursos necessários à compra das fotografias para o Museu Paulista, Taunay, reconhecendo a qualidade da documentação e a importância de tê-la em sua instituição, recorre a outra instância para adquirir o conjunto. Ter imagens de boa qualidade de importantes monumentos nacionais era estratégico para a proeminência e manutenção de um prestígio institucional que o Museu Paulista brigava sofridamente para não perder. A venda das fotografias revela, ainda, uma rede de fotógrafos - grande parte deles estrangeiros - que estabeleceu uma dinâmica de circulação visual pelo país.

Notadamente entre os anos de 1930 e 1950, identifica-se um grande conjunto de fotógrafos brasileiros e estrangeiros que contribuíram definitivamente para formar uma visualidade nacional. Foram esses fotógrafos os responsáveis por dar forma a um discurso visual condizente com a política cultural posta em marcha naquele momento - um discurso elaborado e promovido por atores de grande poder institucional, como Taunay. Trata-se da cultura visual ${ }^{27}$ moderna, inidentificável nos arquivos e ações institucionais. Não foi, portanto, apenas através de veículos impressos de grande circulação, como a revista $\bigcirc$ Cruzeiro, ${ }^{28}$ mas também no interior de instituições públicas que tais fotógrafos contribuíram decisivamente para a formação de uma visualidade moderna e renovada do país. Eric Hess, Marcel Gautherot, Kasys Vosylius, Silvanísio Pinheiro, Benício Whatley Dias e Herman Hugo Graeser representam uma parcela muito pequena das centenas de profissionais que se envolveram em tal empreitada. ${ }^{29}$ De todo modo, eles bem demonstram que as contribuições vieram de fotógrafos com processos e resultados muito variados, bem como distribuídos por todo o território nacional, configurando uma extensa rede de profissionais, o que se efetivou de maneira clara em instituições como o Iphan. ${ }^{30}$
24. Cf. Lacerda (2000).

25. Cf. Goodwin (2001).

26. Carta de Taunay ao fotógrafo Paulo (sic) Stille (13 ago. 1937).

27. Cf. Meneses (2003).

28. Cf. Costa (2012).

29. Cf. Nobre (2001).

30. Cf. Fonseca (2008). 
31. Cf. Lobo (2012).

32. Cf. Benjamin (1992).

33. Cf. Brefe (2005).

34. Cf. Taunay (1920).

35. Carta de Taunay ao fotógrafo José Marques Pereira ( $1^{\circ}$ abr. 1937)

36. Carta de Taunay à senhora Lili de Mendonça (29 ago. 1938).

37. Carta de Taunay ao cônego Luiz Castanho de Almeida (29 ago. 1938).
A importância da rede de fotógrafos para a formação da visualidade no Museu Paulista pode ser notada nas diversas parcerias e contribuições. Merece atenção a solicitação de Taunay ao fotógrafo José Marques Pereira, natural da cidade do Porto, em Portugal, e responsável por uma extensa documentação fotográfica das cidades de São Vicente, Santos e Guarujá, região em que atuava desde sua vinda ao Brasil, no final do século XIX. ${ }^{31}$ Responsável por uma larga documentação de cenas urbanas, em grande parte associadas aos melhoramentos urbanos implementados na cidade do litoral paulista no início do século XX, José Marques Pereira acabou por produzir um conjunto que é referencial no tocante a um imaginário de modernização de Santos, como também de celebração de uma história heroica e nacionalista do país. Se é possível identificar interesse da população em consumir imagens desse processo de transformação, em grande parte sustentado pela difusão de sua produção através de cartões-postais, suporte essencialmente moderno, ${ }^{32}$ o desejo de Taunay, ainda que também passasse por esse ponto, estava na construção de uma narrativa grandiosa da história republicana.

As fotografias requisitadas deveriam retratar o "Pantheon dos Andradas", monumento comemorativo à participação de José Bonifácio de Andrada e Silva e seus irmãos no processo de independência do país. ${ }^{33}$ Para sustentar os argumentos da construção, Taunay já havia redigido o memorial descritivo do monumento, sob patrocínio da Companhia Construtora de Santos, mobilizando também um conjunto de fotografias de José Marques Pereira. ${ }^{34}$ Tal associação revela que a participação do fotógrafo nos projetos de Taunay vinha de longa data, perdurando por quase duas décadas. A requisição para que José Marques Pereira ${ }^{35}$ the encaminhasse outras fotografias era, portanto, fruto de uma aproximação duradoura entre as partes e desempenhava um papel fundamental para o projeto histórico que Taunay buscou construir ao longo de sua gestão à frente do Museu Paulista.

A participação longeva de fotógrafos profissionais em projetos de Taunay se mescla com contribuições esparsas e esporádicas de fotógrafos amadores, cientistas e da própria população, interessada em contribuir com a instituição. A rede era ampla e diversa, mas somente assim se pôde pensar numa ancoragem institucional calcada na fotografia. No mesmo 29 de agosto de 1938, Taunay respondeu a duas cartas a ele endereçadas, em que the foram oferecidas fotografias. Na primeira delas, o diretor agradece a bondade da senhora Lili de Mendonça pela oferta de três fotografias com "interessantíssimas vistas das ruinas do Castelo de Tatuapará". ${ }^{36}$ Assinalada com a mesma data, Taunay encaminha resposta à carta do cônego Luiz Castanho de Almeida, agradecendo pela remessa de fotografias que foram incorporadas à Seção de História do museu. ${ }^{37}$ 
A incorporação desses documentos revela que a formação do arquivo institucional se deu, em grande medida, por meio de ofertas e contribuições esporádicas, com naturezas diversas e muitas vezes divergentes. Nota-se, portanto, que a natureza dos documentos é bastante heterogênea, mas isso não significa que Taunay não tenha se preocupado com a qualidade dos documentos que incorporava à instituição. Mesmo os materiais ofertados por "anônimos" precisavam passar pelo crivo final do diretor. Essa era uma prática cotidiana, que rendia elogios ou largas críticas. Como se pode ver na própria resposta encaminhada à senhora Lili de Mendonça, tais documentos seriam para Taunay "as primeiras fotografias nítidas destas ruínas que eu vejo. $\bigcirc$ mais tem-me aparecido em clichés horríveis".

$\bigcirc$ cuidado em incorporar registros fotográficos de qualidade era um dos princípios para a aceitação dos documentos, ainda que vindos de origens muito diversas; a premissa era a da qualidade e não apenas a da relevância do tema documentado. Essa questão reaparece em dezenas de outros documentos, como quando Taunay agradece ao fotógrafo Alypio Leme de Oliveira pelas excelentes reproduções fotográficas relativas à cartografia. Segundo Taunay, as fotografias "Não estão boas, estão magnificas. Não penso jamais ter visto trabalho tão bem feito em matéria de reprodução cartográfica". $\bigcirc$ diretor do Museu Paulista solicita, por fim, três cópias do conjunto que remeteria ao Instituto Histórico de S. Paulo, à Biblioteca Nacional e ao Instituto Histórico Brasileiro. ${ }^{38}$

Os resultados incorporados ao acervo do museu, especialmente aqueles destinados à Seção Histórica, são fruto do controle exercido por Taunay, definindo quais e como esses materiais seriam. Uma das mais importantes evidências disso se refere ao controle da produção do fotógrafo Frederico Egner, comprometido com a documentação do Museu Republicano. Em carta encaminhada em 22 de agosto de 1935, Arthur Sampaio, responsável pelo Museu Republicado, destacou a Taunay que o fotógrafo gostaria de saber quantas imagens de cada sala do museu deveriam ser capturadas. Dois dias mais tarde, Taunay responde à solicitação nos seguintes termos: "Recebi a sua carta. É melhor o Sr. Egner não fazer cousa alguma antes de eu ir ahi. É um homem complicado e é capaz de não fazer o que eu desejo. Portanto diga-lhe que espere a minha ida a Ytú" ${ }^{39}$ A recomendação de Taunay revela não apenas o forte controle que o diretor exercia sobre a produção dos documentos, mas destaca, em especial, a importância da fotografia no Museu Paulista. $\bigcirc$ cuidado e o controle no processo de produção da documentação evidenciavam que era preciso organizar não apenas um conjunto de documentos que apresentassem aspectos da cultura brasileira, mas um arquivo referencial de qualidade e capaz de dar voz às narrativas e aos projetos institucionais, reforçando o rigor científico da prestigiosa instituição.
38. Carta de Taunay ao fotógrafo Alypio Leme de Oliveira (22 maio 1935).

39. Carta de Arthur Sampaio a Taunay (22 ago. 1935), com resposta em 24 de agosto de 1935. 
40. Carta de Taunay ao fotógrafo Alypio Leme de Oliveira (22 maio 1935).

41. Cf. Costa (2018).

42. Cf. Carvalho (1997). interesse em controlar a qualidade dos documentos fotográficos qualifica, em grande medida, a compra do laboratório fotográfico. Se era preciso ter domínio sobre aquilo que viria a ser incorporado na instituição, a compra dos equipamentos não apenas diminuiria altos custos de contratação dos fotógrafos externos, mas também traria maior controle sobre a produção de fotografias. E é importante deixar claro que essa relação não se dava apenas na Seção de Zoologia, que pagava altos preços por serviços de terceiros, grande parte deles sem o conhecimento científico necessário. A Seção de História também fez uso do laboratório, demandando rigorosos registros para suas atividades.

É fundamental destacar que havia certa diversidade de usos da documentação, desdobrando-se numa heterogeneidade, hoje arquivada e preservada pelo Museu Paulista. Um dos usos mais importantes da documentação fotográfica era a reprodução de iconografias pertencentes a instituições públicas e privadas. Essa documentação servia essencialmente para fornecer referências às atividades de pesquisa e, eventualmente, como registro de um objeto ou personalidade relevante para a narrativa histórica do país. Em curta mensagem encaminhada ao fotógrafo Quinto Lazzarini, Taunay avisa que tinha "um serviço para o Snr. de photographia de dous quadros a óleo e de uma aquarella. Queira falar-me pelo telefone". ${ }^{40}$ A rápida mensagem encaminhada expõe a necessidade do registro de obras de arte, requisição frequente para atividades institucionais. Ainda que não se saiba a quais telas e a qual aquarela Taunay se referia, a documentação dessas obras de arte buscava não apenas constituir um referencial iconográfico para o museu, mas fornecer orientações para os projetos intelectuais de Taunay. $\bigcirc$ registro iconográfico por meio da fotografia foi a estratégia adotada por muitos museus nacionais no decorrer da década de 1930. Um exemplo pode ser identificado na produção de telas e aquarelas para a Inspetoria dos Monumentos Nacionais, também na década de 1930,41 em que José Wasth Rodrigues, Hans Nobaver e Alfredo Norfini fizeram constante uso de fotografias para a produção de suas obras. Esse uso encontra na produção de José Wasth Rodrigues um dos exemplos mais emblemáticos. Para a série de telas produzidas para o Museu Paulista, Wasth Rodrigues utilizou fotografias realizadas por Militão Augusto de Azevedo, transformando imagens da virada do século XIX para o XX em cenas de um idílico passado colonial para a cidade de São Paulo. ${ }^{42}$ Esse é talvez um dos casos mais reveladores da associação entre fotografia e pintura, já que recriam deliberadamente um passado imaginado e idealizado, condizente com a narrativa histórica proposta pelo museu.

Tal prática era recorrente e estruturante da política implementada por Taunay. No início do ano de 1930, o diretor do Museu Paulista e Ottilia P. de 
Paula Leite, conservadora do Museu Republicano, organizaram uma campanha nos jornais da cidade de ltu, solicitando que familiares dos participantes da Convenção de ltu encaminhassem fotografias de tais personalidades. Em 16 de março de 1930, Paula Leite relata a Taunay que recebera um novo conjunto de fotografias, com as quais já totalizavam vinte, restando apenas 45. A notícia foi recebida por Taunay como um grande sucesso; o diretor assinalou, em carta datada de 18 daquele mesmo mês, possuir mais uma fotografia, além de informar problemas pontuais, como a recusa de Jonas de Barros em conceder uma das fotografias. ${ }^{43}$ Esses documentos serviriam posteriormente para pintores executarem os retratos dos confederados, que viriam a ser expostos no interior do Museu Republicano e, assim, narrar em tom grandioso a mobilização de tais personagens. A estratégia de aquisição da documentação fotográfica para esse empreendimento revela um dos usos da fotografia. Nesse caso, ela servia como referência visual para a produção das obras de arte que viriam a ser expostas no museu. Institucionalmente, permitiase o uso da fotografia no processo de feitura das obras, mas não sua incorporação como obra de arte no interior do museu, estatuto que seria modificado apenas no final da década de 1960 no Brasil. ${ }^{44}$ A fotografia tomada como suporte para outras ações foi prática recorrente, servindo às urgências institucionais no Brasil dos anos 1930, momento em que pouco se sabia sobre acervos e arquivos fotográficos ou mesmo sobre o que se podia encontrar fora dos circuitos consagrados. Foi com essa mesma prática que Rodrigo Mello Franco de Andrade, recorrendo a uma campanha divulgada pelo jornal $\bigcirc$ Globo, conseguiu reunir uma importante documentação fotográfica sobre os monumentos espalhados pelo Brasil, possibilitando o início das atividades de pesquisa para o tombamento do patrimônio nacional. ${ }^{45}$

Ao mesmo tempo que se identifica o uso da fotografia como suporte de informações iconográficas, é evidente sua associação a um campo mais científico ou objetivo para a produção intelectual. $\bigcirc$ Arquivo do Museu Paulista não deixa dúvidas sobre esse aspecto, permitindo reconhecer diversas solicitações de reprodução de documentação. Um caso eloquente refere-se ao pedido realizado em 31 de maio de 1937 por Mário de Andrade, solicitando, a pedido do amigo comum sr. Lamego, "cópia fotográfica de documento que está atualmente sob a mais que competente guarda" do diretor. ${ }^{46}$ Embora o documento não esteja explicitado na carta, ele não deixa dúvidas quanto ao uso da fotografia como meio de reprodução de documentos textuais. Tal prática aparece em muitos outros momentos no decorrer dos anos 1930, como quando Taunay, em resposta ao dr. Clement André, avisa que solicitaria ao "Museu Nacional, do Rio de Janeiro, photographias das pranchas afim de poder verificar se correspondem aos typos que desejaes conhecer". ${ }^{47}$ Em outro momento, Taunay responde ao professor
43. Carta de Ottilia P. de Paula Leite a Taunay (16 mar. 1930), com resposta em 18 de março de 1930.

44. Cf. Costa (2008).

45. Cf. Andrade (1987).

46. Carta de Mário de Andrade a Taunay (31 maio 1937).

47. Carta de Taunay ao dr. Clement André (3 nov. 1933). 
48. Ihering (1911).

49. Documento $\mathrm{n}^{\circ} 1412$ do Almoxarifado da Secretaria de Estado da Educação e da Saúde Pública, descrevendo o lançamento de verba no orçamento vigente para a compra dos equipamentos do Laboratório Fotográfico. (Arquivo do Museu Paulista, 7 de junho de 1937). uruguaio B. Sierra y Sierra autorizando a reprodução de estampas publicadas na Revista do Museu Paulista, que seriam úteis para o seu trabalho. A fotografia permitia, assim, que um pesquisador residente em Paris ou no Uruguai recebesse documentos de uma instituição brasileira sem a necessidade de se deslocar para realizar a pesquisa. Era possível, ainda, produzir uma fotografia a partir de uma estampa encontrada em uma revista científica. Estava em curso uma revolução nos modos de pensar e fazer o trabalho intelectual.

O emprego da fotografia se multiplicava na mesma velocidade de sua popularização, fomentando uma verdadeira revolução institucional na aplicação de tais recursos. Não é de estranhar, portanto, que no decorrer dos anos 1930 as ações do museu tenham se intensificado na relação com a produção fotográfica. As atividades desenvolvidas pelos naturalistas expressam essa aproximação, com incursões pelo interior do país que requeriam cada vez mais o uso da fotografia. "Naturalista, caçador e fotógrafo" - assim identificado por Taunay em carta de 25 de julho de 1934 -, Walter Garbe ocupava um lugar importante no reconhecimento dos indígenas do interior do país, desde o início do século XX. Foi ele o responsável por uma série fotográfica que documentou os Botocudos do Rio Doce, tema tratado em artigo homônimo, de autoria do então diretor do Museu Paulista, Hermann von Thering. ${ }^{48} \mathrm{Na}$ década de 1930, Garbe continuava a atuar no museu, aprofundando a popularização da fotografia nas incursões dos naturalistas e nos relatórios e investigações científicas produzidos pela Seção de Zoologia.

A leitura do documento descritivo de compra do laboratório fotográfico expõe, nas especificidades de seus componentes, a diversidade dos usos anteriormente descritos. Nele, nota-se a fotografia destinada tanto à zoologia quanto à reprodução de documentos e obras de arte, usos vinculados mais claramente com a Seção de História:

Laboratório fotográfico completo, devidamente instalado, constando de: 1 camara 18x18 p. reprodução e micro-fotografia, c/3 chassis especiais p. uma chapa e transferidores, c/ cano metálico s/ respectivo jogo c/ obturador, montada em cavalete c. Os movimentos horizontais e verticais, c/os respectivos suportes p. lâmpadas reflectoras e objetivas adaptavais, sendo uma micro de 42 mms., uma dupla-Anastigmat de 180 mms., e uma de 135 mms. Dupla-Anastigmat 1:4,5.; - 1 ampliador $13 \times 18 \mathrm{c} /$ condensador tipo vertical, adaptado p. micro fotografia e ampliações normais. - 1 tripé "Universal" número 2; - 1 mesa p. revelação, de 150×60, forrada c/ lençol de chumbo; - 2 mesas, uma p. cópias e outra p. ampliações; - 2 prateleiras para laboratório; - e Instalação elétrica interna no laboratório, com 7 lampadas de cores, de acordo com as necessidades. ${ }^{49}$ 
Existe clara associação entre a compra do laboratório e os usos voltados à Seção de Zoologia, que acabou por se responsabilizar pela operação de tais equipamentos. Nota-se, por exemplo, que a câmera adquirida se destinava não apenas à reprodução convencional de documentos, mas também à microfotografia. Mais adiante, o documento assinala que o condensador do ampliador estava adaptado à microfotografia, além das reproduções consideradas "normais", ou seja, tanto o conjunto de lentes como a estrutura do condensador estavam adaptados para trabalhos ligados à zoologia. A microfotografia estabelecia uma relação direta com os trabalhos científicos desenvolvidos pelos naturalistas, que muitas vezes estiveram mobilizados em torno da descrição de novas espécies de plantas e insetos. Para tanto, requeriam minuciosas exposições de estruturas biológicas, demandando desenhos científicos legíveis e organizados, o que era suprido pela fotografia, ainda que limitada em seus componentes tecnológicos.

Os desdobramentos da compra do equipamento não se restringiram, no entanto, às atividades ligadas à Seção de Zoologia. No relatório anual de 1938, elaborado após essa compra, Taunay descrevia que o museu reproduziu telas da Exposição Comemorativa do Cinquentenário da Lei Áurea, destacando que

incumbiu-se da reprodução fotográfica e das ampliações (feitas no laboratório fotográfico da Seção de História Natural) o Sr. Carlos Amadeu de Camargo Andrade, naturalista-viajante, o qual, segundo tive ocasião de saber, foi auxiliado nos retoques por D. Luiza Fonseca, desenhista do Museu. ${ }^{50}$

uso do laboratório aparece, portanto, associado não apenas às atividades dos naturalistas, mas eles próprios, por dominarem o uso técnico do equipamento, foram responsáveis por documentações destinadas à Seção de História. $\bigcirc$ laboratório era, portanto, de uso comum dos servidores do museu, e seu emprego assumia formas de acordo com cada especificidade científica.

A prática de documentação fotográfica, que culminou na compra do laboratório em 1937, passou a ocupar um tempo considerável das atividades do museu, avolumando-se significativamente no decorrer dos anos 1930. diálogo com tal suporte fez o número de documentos fotográficos aumentar velozmente no Museu Paulista, pressionando a instituição a criar uma sistematização de arquivo que incorporasse tais documentos, em especial na Seção de História. No relatório anual relativo ao exercício de 1934, Taunay revela que criou um Arquivo Fotográfico para atender às necessidades do museu, destacando os seguintes termos: 
51. Arquivo do Museu Paulista (1934, p. 18).
Como este acervo esteja representado por uma série de chapas bastante numerosa lalgumas mesmo valiosas) reproduzindo aspectos do Museu quer interna e externamente, organizei em fichas para maior facilidade na procura e existência de uma ou outra chapa em nosso archivo.

Terminado este trabalho, verificou-se possuir o Museu 614 chapas que se acham cuidadosamente archivadas. ${ }^{51}$

As chapas fotográficas se avolumavam, e o museu se viu forçado a organizá-las, ainda sem uma sistematização. As demandas institucionais impulsionaram, portanto, a criação do Arquivo Fotográfico em 1934, assim como a compra do laboratório fotográfico, em 1937, e de outros equipamentos em 1938. Desse modo, no decorrer dos anos 1930 o Museu Paulista passava a pensar a fotografia como instrumento imbricado com sua estrutura de funcionamento. Mas vale destacar que tal empenho na aquisição desses equipamentos se deu, em grande parte, em função de uma demanda nacional e internacional que reconhecia no bom uso dos documentos fotográficos a seriedade científica das instituições. Havia, portanto, uma pressão da comunidade acadêmica para que os cientistas e as instituições dedicadas à pesquisa incorporassem em suas dinâmicas não apenas o debate, mas o uso dos documentos fotográficos. Não por menos, é possível reconhecer nos meios de circulação dessas imagens o lugar de pressão acadêmica que, por fim, contribuiu decisivamente para as ações institucionais do Museu Paulista ligadas à fotografia.

\section{A FOTOGRAFIA IMPRESSA E A PENÚRIA ORÇAMENTÁRIA}

A fotografia possui uma característica que é primordial para o reconhecimento do seu lugar no século XX. Compreender o interesse de museus, institutos ou bibliotecas nacionais e internacionais por constituir acervos, laboratórios ou práticas de documentação fotográfica pressupõe necessariamente reconhecer o modo como as fotografias chegavam até tais instituições ou mesmo como estas divulgavam tais imagens. As fotografias que acabaram por constituir um Arquivo Fotográfico do Museu Paulista visavam instrumentalizar pesquisas ou atividades ligadas à produção de telas artísticas. Em ambos os casos, a visibilidade das fotografias arquivadas ou mesmo o acesso a elas estiveram restritos a um circuito muito pequeno de servidores e artistas, chegando ao grande público em circunstâncias eventuais. A documentação de maior visibilidade, que chegou ao maior número de pessoas, refere-se àquela apresentada na Revista do Museu 
Paulista. Os Botocudos do fotógrafo Walter Garbe, por exemplo, foram rapidamente identificados pelos acadêmicos e cientistas - não por que estes conheciam toda a série realizada pelo fotografo alemão, mas por que tiveram acesso ao conjunto de imagens apresentado no tomo VIII da Revista do Museu Paulista. A pressão pela incorporação da fotografia advinha justamente da sua circulação nos impressos.

O relatório do exercício de 1930 é de grande importância para entender o que se passava no Museu Paulista e o lugar da fotografia na estrutura institucional. Outros relatórios também trazem significativas anotações, mas, de forma geral, eles se repetem perante uma dinâmica que pouco se alterou no decorrer da década de 1930. O primeiro relatório da época é bastante completo na sua diversidade temática, apresentando de maneira eloquente a complexidade imposta institucionalmente no que se refere à fotografia. No item dedicado às publicações, Taunay relata os esforços destinados à Revista do Museu Paulista, revelando as complicações envolvidas na sua impressão e, em especial, o lugar ocupado pela iconografia num debate internacional. No primeiro parágrafo, o diretor do museu relata que:

Havendo-se desmanchado o principal prelo daquella officina não puderam os nossos originais entrar em composição nada se fazendo no "Diário" do volume anunciado para princípios de 1931. Infelizmente faltou-nos o apoio a que já estávamos desde tantos anos habituados por parte do "Diario Official". 52

principal prelo do Diario Official, responsável até então pela impressão da revista, passava por reforma que duraria até o final de 1931 . Essa situação prejudicou a dinâmica de impressão do tomo da revista, o que em parte foi resolvido com a contratação dos serviços da Typographia Ideal, uma empresa privada que, em concordância com o Diário Oficial, receberia o papel já à disposição da gráfica, além de separar em dois volumes a publicação do tomo referido. $\bigcirc$ problema se resolvia de maneira drástica e as consequências se arrastariam por mais alguns anos.

A questão mais latente nesse processo, se já não bastassem as dificuldades com o prelo, refere-se aos vultosos recursos consumidos para a impressão da revista. No relatório de 1930, lê-se a seguinte descrição: "Não houve remédio senão recorrer a um verdadeiro sacrifício para a impressão do primeiro volume do tomo a custa da verba do Museu o que representa sério desfalque da nossa minguada dotação." 53 O Projeto de Dotação Orçamentária apresentado no dia 2 de junho de 1930 revela um total de 75 contos de réis destinados ao museu, sendo 10 deles designados à "Impressão de estampas para a 'Revista". 54 Ao contrário da fotografia, que consumiu pouco mais de $1 \%$ dos recursos, foram
52. Arquivo do Museu Paulista (1930, p. 55).

53. Arquivo do Museu Paulista (1930, p. 55).

54. Carta de Taunay ao dr. A. Meirelles Reis Filho, subdiretor da Secretaria do Interior (2 jun. 1930). 
55. Arquivo do Museu Paulista (1933, p. 38-39). gastos mais de $13 \%$ do orçamento do museu com a impressão da revista, que, ainda assim, não pôde ser impressa por conta das mudanças no prelo do Diario Official. A dramaticidade da situação era evidente e ganhava ares ainda mais amargos com o crescente declínio orçamentário, descrito minuciosamente por Taunay no relatório do exercício de 1933. Os escassos 80 contos destinados ao museu antes de 1930 passaram a $42 \mathrm{em}$ 1933, provocando um "verdadeiro colapso na vida do nosso Instituto" e fazendo Taunay apelar ao secretário para "melhorar as apertadíssimas, as angustiosas condições financeiras do nosso Instituto que no entanto é, certamente, um dos mais elevados paradigmas da civilização em S. Paulo". ${ }^{55}$ No ano de 1934 chegou-se à marca limite de 31 contos de réis, pagos em 21 prestações, comprometendo o bom funcionamento da instituição e o pagamento de itens básicos. A penúria assolava o Museu Paulista, ao mesmo tempo que aumentavam as pressões para que se publicassem novos tomos da Revista do Museu Paulista. Essa situação seria revertida somente na segunda metade da década de 1930; em 1937 - justamente quando se adquiriu o laboratório fotográfico - o Museu Paulista recebeu verba de 102 contos de réis.

A dramática situação não pode ser assimilada por completo se apenas for considerada a falta de verbas para a publicação de novos números da Revista do Museu Paulista. Os altos custos mobilizados para a impressão destacam que algo a mais acontecia no mundo científico e acadêmico. Mesmo com os 102 contos de réis disponíveis no ano de 1937, os custos de publicação ainda representavam 10\% desse valor, parcela considerável para uma instituição do porte do Museu Paulista. Observando-se novamente o relatório anual do exercício de 1930, notase que o que estava em jogo naquele momento era o prestígio institucional. Segundo Taunay:

Qualquer atraso na distribuição do nosso velho e prestigioso órgão causa extranheza nos meios scientíficos do Universo, provocando numerosas e por vezes vexatórias interpelações dos museus estrangeiros, sobretudo norte americanos, muitos dois quaes chagam a aventar a possível cessação dos nossos trabalhos scientíficos!

O relato apresentado nesse documento é sensível para compreender as consequências provocadas pelo atraso da publicação. O Museu Paulista dependia da constância na publicação de sua revista para não perder o prestígio no "Universo". O tom exagerado é reflexo da gravidade provocada pelo atraso. Não era possível que uma instituição do nível do Museu Paulista deixasse de se posicionar academicamente, e Taunay sabia das consequências acadêmicas que a situação poderia provocar. $\bigcirc$ cenário era grave e de difícil compreensão para 
a burocracia do Estado, moroso em reconhecer a urgência da situação. $\bigcirc$ que estava em jogo era o prestígio institucional do Museu e, nas palavras de Taunay, "Esta Diretoria tem como ponto de honra manter a Revista do Museu Paulista à altura do seu já antigo renome e envidará todos os esforços para que o tomo XVII não desmereça dos seus antecessores". ${ }^{56}$ Era preciso publicar a revista a qualquer custo.

Inicialmente, vale reconhecer que o Museu Paulista participava de uma ampla rede científica, a qual incorporava universidades, museus, laboratórios, bibliotecas e outras instituições espalhadas por todos os continentes. Apesar das consequências da crise econômica de 1929, quando o número de permutas revelava um decréscimo notável, o relatório anual do exercício de 1933 permite ter uma ideia da importância do Museu Paulista nesse contexto. Segundo o documento, o Museu recebeu naquele ano um total de 1763 publicações provenientes de 44 países, dentre os quais se destacam: os Estados Unidos (EUA), com 414 publicações; a Alemanha, com 149; a Bélgica e a França, com 107 publicações cada uma; a ltália, com 99; ao lado de diversos outros países como Austrália, Argentina, Canadá, Chile, Espanha, Portugal, Japão, México, Rússia, Suiça e Tchecoslováquia, além do próprio Brasil. ${ }^{57}$ Se o número de países impressiona e faz jus à preocupação com um possível decréscimo de prestígio do Museu Paulista no cenário internacional, as instituições com que Taunay estabelecia contato eram das mais importantes. As cartas arquivadas no Museu Paulista revelam diálogos com o Field Museum of Natural History, o Smithsonian Institution e a Stanford University, nos EUA; a Sociedad Geographica do Sucre, na Bolívia; o Boletín Bibliográfico de Anthropologia Americana, no México; e tantas outras mais. - Museu Paulista era, iá na década de 1930, uma instituição renomada, em grande parte pela projeção que sua Seção de Zoologia alcançara nos anos anteriores.

Era por meio da permuta de publicações que se consolidavam tais relações. É possível identificar tanto no Museu Paulista quanto no atual Museu de Zoologia, criado no final dos anos 1930, coleções bibliográficas completas de periódicos seminais como a Zoological Record e o Bulletin of The American Museum of Natural History, o que não é pouco, mesmo para uma renomada instituição internacional. conjunto de publicações reunido pelo museu representava já no decorrer dos anos 1930 um volume considerável, que implicava em problemas estruturais para seu funcionamento. É diante dessa numerosa coleção que Taunay inicia a campanha para que o Museu fosse contemplado com um novo edifício, capaz de abrigar tais publicações, além de ampliar as dependências para as avolumadas atividades da instituição. Como se pode ver no relatório anual do exercício de 1938:
56. Arquivo do Museu Paulista (1930, p. 55).

57. Arquivo do Museu Paulista (1933, p. 23). 
58. Arquivo do Museu Paulista (1938, p. 4).

59. Cartas de Taunay ao gerente da Secção Fiscalização Bancária do Banco do Brasil (24 jun. 1935, 9 out. 1935).
De ano para ano avultam notavelmente as nossas coleções pelo trabalho encarniçado da coleta dos naturalistas e o concurso das dádivas, das permutas e das aquisições.

A nossa Biblioteca recebendo mais de dois mil livros por ano, já contem mais de cincoenta mil livros.

Para o imenso material, por nós armazenando, escasseia sobretudo o espaço. Nos grandes museus do mundo a área reservada às coleções em série é, no mínimo, o dobro da que se destina às salas de exposição pública.

No Museu Paulista dá-se o inverso. ${ }^{58}$

Era preciso aumentar radicalmente o espaço, duplicá-lo, para que acompanhasse o crescimento dos museus modernos, com os quais o Museu Paulista mantinha relações científicas e institucionais que pretendia manter. Mas se o acervo de revistas, hoje sob guarda do Museu de Zoologia, se apresenta como evidência relevante do papel ocupado pelo Museu Paulista nos anos 1930, vale destacar outros dois documentos de grande significado para tal entendimento.

No ano de 1935 Taunay solicitou ao Banco do Brasil duas licenças para despachar caixotes com material zoológico para os EUA; em 24 de junho solicitou o envio de um caixote contendo "couros de aves" para o Field Museum of Natural History, em Chicago, e em 9 de outubro solicitou o envio de "um caixote contendo material zoológico para estudos scientificos ao Snr. A. Wetmore, da Smithsonian Institution, em Washington". ${ }^{59}$ As duas instituições em questão são das mais respeitadas e prestigiosas do campo científico, especialmente se considerado o fato de que a Europa se recuperava da Primeira Grande Guerra e os EUA iniciavam uma marcha consistente para sua consolidação como potência mundial, não apenas econômica, mas também intelectual. Esses dois documentos revelam uma consistente rede de cientistas, o que não se restringiu às instituições estadunidenses, visto que o Museu Paulista também recebeu aves, cascos de tartaruga, rochas e outros objetos científicos de diversas instituições da América do Sul. E não recebeu materiais de instituições fora dessa região, pois, como destacado pelo próprio Taunay em mais de uma ocasião, os interesses do museu se restringiam às especificidades brasileiras e, portanto, inviabilizavam o recebimento de material proveniente de outras regiões. O Museu Paulista era uma instituição consolidada, e seu prestígio advinha em grande medida de sua contribuição para os avanços científicos compartilhados em rede internacional, em que os impressos assumiam um papel fundamental. Divulgar os avanços científicos do Museu Paulista, projetando a visibilidade institucional, era necessidade de primeira ordem para manter o prestígio conquistado após pesadas e dedicadas investigações científicas. 
O atraso na publicação do tomo XVII da Revista do Museu Paulista não era, portanto, apenas um problema de ordem burocrática, mas sério entrave à manutenção do prestígio do Museu Paulista no mundo científico. Quanto a esse aspecto, Taunay alertou ao secretário de Estado dos Negócios da Educação e Saúde Pública que o problema era ainda mais sério e complexo, visto que estava em curso uma radical mudança nos processos gráficos, com pesadas consequências para o mundo científico. Um trecho do relatório anual do exercício de 1930 é singular a esse respeito:

Sabe V. Ex. quanto dia a dia crescem as exigências de ilustrações dos periódicos scientíficos.

Póde-se mesmo dizer que imprimir volumes sem iconografia é prejudical-os imenso; impor-the verdadeira captis diminuto.

A descrição de espécies novas exige estampas, os naturalistas recusam-se a entregar colaboração, alegando falta de iconographia. E este hoje esta cada vez mais cara. Para manter o nível da nossa Revista temos de fazer verdadeiros sacrifícios dadas as nossas exíguas verbas, sacrifício sobretudo de tempo, pois que com um exercício financeiro não nos é possivel pagar de vez todas as estampas de um tomo. ${ }^{60}$

Publicar uma revista sem iconografia era torná-la desprezível no mundo científico dos anos 1930. Do mesmo modo, um artigo que não mobilizasse fotografias na sua apresentação passava a ocupar um lugar subalterno num mundo extremamente visual, sedento por ver provas concretas dos argumentos. $\bigcirc$ poder e o prestígio institucional dependiam da publicação de imagens em seus meios de divulgação, especialmente em periódicos.

Uma consulta na Biblioteca do Museu de Zoologia permite identificar tal fenômeno no início dos anos 1930. $\bigcirc$ Bulletin of The American Museum of Natural History é citado nos relatórios de atividades como uma das publicações de maior prestígio internacional e que vinham sendo adquiridas pelo Museu Paulista através de permutas institucionais. As centenas de páginas dessa publicação trazem essencialmente textos corridos, tabelas, dezenas de ilustrações científicas e uma pequena quantidade de fotografias. Os números não impressionam o leitor do século XXI, mas o impacto de tais ilustrações pode ser compreendido não apenas pela qualidade das imagens, mas também pelo tamanho ocupado por elas nas páginas, como no detalhe extraído do volume 59 (Figura 2 - imagem à esquerda). Dispondo de vultosos recursos orçamentários, os museus dos EUA parecem mesmo ter pressionado instituições irmãs espalhadas por todo o globo. No mesmo período, o Muséum National d'Histoire Naturelle publicou, no número 6 de seu boletim, um
60. Arquivo do Museu Paulista (1930, p. 56). 
conjunto menor e mais modesto de fotografias de alguns insetos e corais (Figura 2 - imagem à direita). Ao contrário do periódico dos EUA, a publicação francesa não apresentou muitas fotografias, mas, quando o fez, as representações eram de dimensões inferiores. No entanto, em se tratando de uma revista científica de renome internacional, não espanta que ela tenha apresentado, por menores que fossem, fotografias dos temas e objetos tratados.
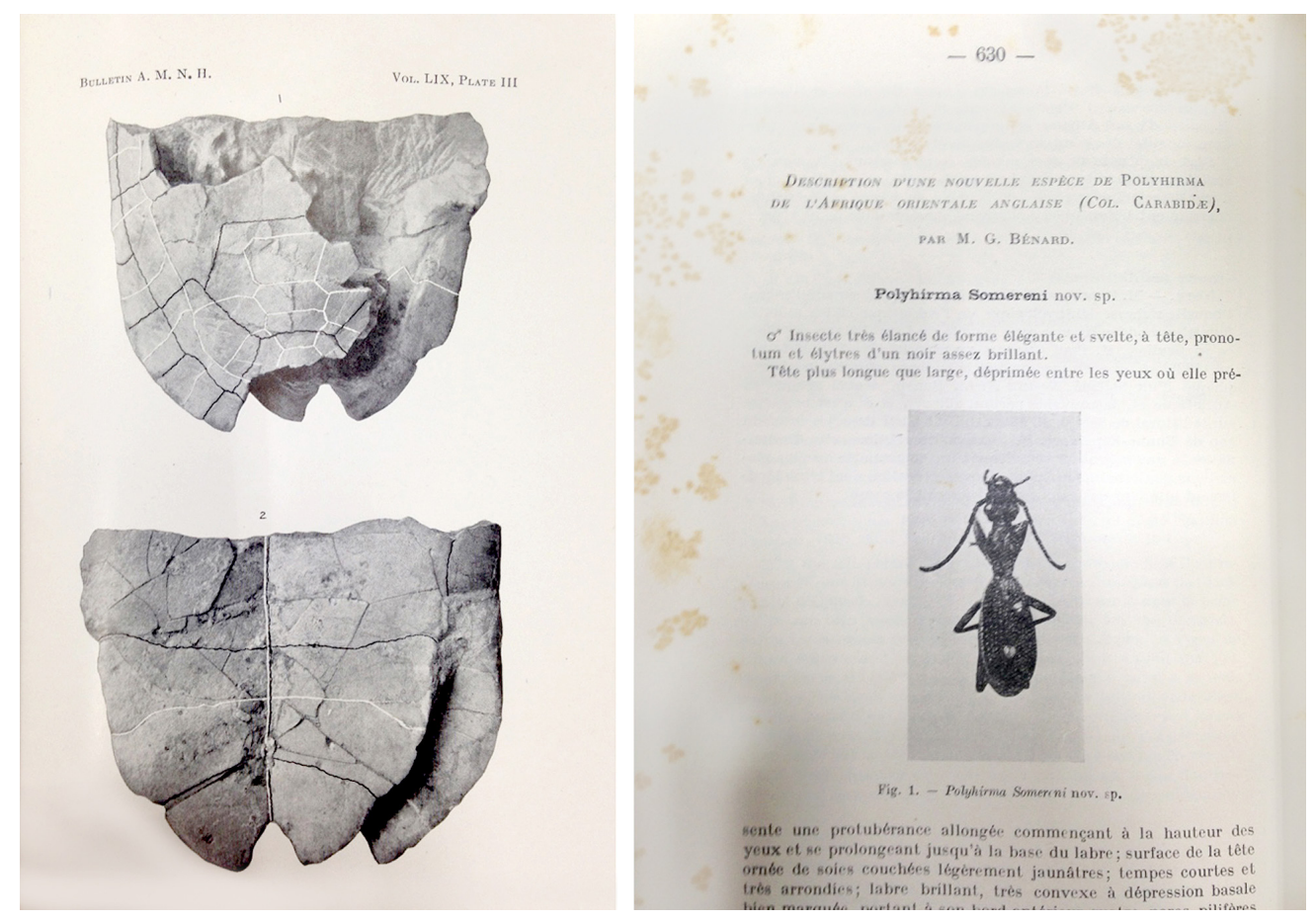

Figura 2 - À esquerda detalhe do Bulletin of The American Museum of Natural History, v. 59, 1929-1933 onde se vê duas fotografias de vistas de um casco de tartaruga. À direita, detalhe do Bulletin du Muséum National d'Histoire Naturelle. 2. série - tomo II. nº 6, nov. 1930, onde se vê a fotografia de um inseto.

No mesmo período em que Taunay lutava para incorporar cada vez mais fotografias às edições da Revista do Museu Paulista, as renomadas revistas internacionais também pautaram seus avanços científicos usando fotografias e não mais apenas ilustrações. A fotografia cumpria o papel de prova irrefutável, permitindo que os artigos fossem tomados com a seriedade desejada. No entanto, a incorporação de fotografias na publicação do Museu Paulista se deu de maneira pontual, atendendo às necessidades imprescindíveis num primeiro momento. $\bigcirc$ problema da fotografia, bem como o da iconografia de forma mais abrangente, aparece em dezenas de cartas trocadas entre o diretor do Museu Paulista e 
pesquisadores e cientistas. Em carta de 6 de fevereiro de 1937, por exemplo, Taunay responde ao Padre Murillo Moutinho a respeito da obra que o destinatário pretendia empreender. Fica claro na sua argumentação que, embora a obra fosse monumental e de extrema relevância para as pesquisas históricas brasileiras, era preciso considerar os recursos financeiros disponíveis para o empreendimento editorial. Não seria possível publicar obra de tamanho vulto - comparável, para Taunay, ao Monumentae Historie Germania, publicado em 1826 por Heinrich Friedrich Karl Freiherr von Stein - sem a ajuda do Estado, já que suas "seiscentas pranchas fac-similares em zincographia" tornariam a publicação um empreendimento caríssimo. ${ }^{61}$

Questão semelhante aparece mais diretamente relacionada à proposta de artigo de Antônio Serrano, que foi prontamente aceita com honra pelo diretor do Museu Paulista. No entanto, Taunay relata que naquele momento a grande dificuldade a ser vencida era financeira, e acrescenta que: "Se o seu artigo tem abundante iconographia neste momento por motivos de despesas impossíveis de se realizar, não nos é possível publicar o seu trabalho".62 Ainda que o autor fosse renomado e, por isso, trouxesse notoriedade à revista, não era possível incorporar artigos com elevado uso de recursos iconográficos. $\bigcirc$ parco orçamento não apenas restringia a publicação de novos estudos científicos, mas dificultava a projeção e o reconhecimento da revista, o que não significa, todavia, falta de empreendimentos vultosos associados à iconografia. No relatório anual do exercício de 1939, Taunay descreve as imensas despesas com a publicação da tradução do compêndio Historia Naturalis Brasiliae, publicada originalmente em latim no ano de 1648, pelo médico e naturalista holandês Guilherme Piso. Gastaram-se demasiados recursos para a produção de fotografias, clichés e para o pagamento de comentários, faltando ainda remunerar os "excelentes serviços do Dr. Paulo Sawaya na parte referente a vertebrados (mamíferos e peixes)". ${ }^{63} \bigcirc$ monumental empreendimento editorial pôde ser publicado apenas no ano de 1948, para as comemorações do cinquentenário do Museu Paulista, ${ }^{64}$ ainda contando com relevantes recursos financeiros do Estado, advindos exclusivamente para tal projeto. Pela data comemorativa, pode-se ter uma ideia da relevância de tal publicação e, ainda, da precisa escolha de um livro extensamente ilustrado. Era preciso comemorar os cinquenta anos com uma publicação ricamente ilustrada, dando ensejo à notoriedade institucional do Museu Paulista.

A iconografia e especialmente a fotografia ganharam um papel relevante na história institucional do Museu Paulista no decorrer da década de 1930. Não é mero acaso, portanto, a contemporaneidade entre o uso de fotografias nas publicações científicas e a compra do laboratório fotográfico pelo museu. Se era preciso manter - prestígio institucional perante uma demanda cada vez maior por publicações ilustradas com fotografias, um laboratório fotográfico contribuiria da melhor maneira
61. Carta de Taunay ao Padre Murillo Moutinho (6 fev. 1937).

62. Carta de Taunay a Antônio Serrano (11 mar. 1933).

63. Arquivo do Museu Paulista (1939, p. 30).

64. Cf. Piso (1948). 
65. Arquivo do Museu Paulista (1939, p. 1). para a profusão dos avanços científicos. Tal constatação é feita por Taunay no relatório do exercício de 1937, ao destacar que aquele ano foi um "dos mais fecundos sob todos os pontos de vista". ${ }^{5}$ Após anos de penúria no Museu Paulista, Taunay festeja a "paz" institucional. O cenário descrito pelo diretor do museu decorria diretamente da compra do laboratório fotográfico, que imediatamente dava frutos na forma de artigos científicos publicados na Revista do Museu Paulista. Era isso o que relatava o chefe da Seção de Zoologia, ao destacar que os excelentes resultados da compra do laboratório fotográfico podiam ser apreciados em artigos inéditos publicados no tomo 23 da revista. A compra do laboratório serviu como um divisor de águas para a instituição, fomentando a publicação de investigações represadas pela falta de recursos iconográficos. Tal mudança pode ser apreendida nas páginas do referido tomo, que apresentou, dentre outros estudos, novas espécies de insetos, como no Esboço Monográfico dos Anoplodermídeos (Figura 3).

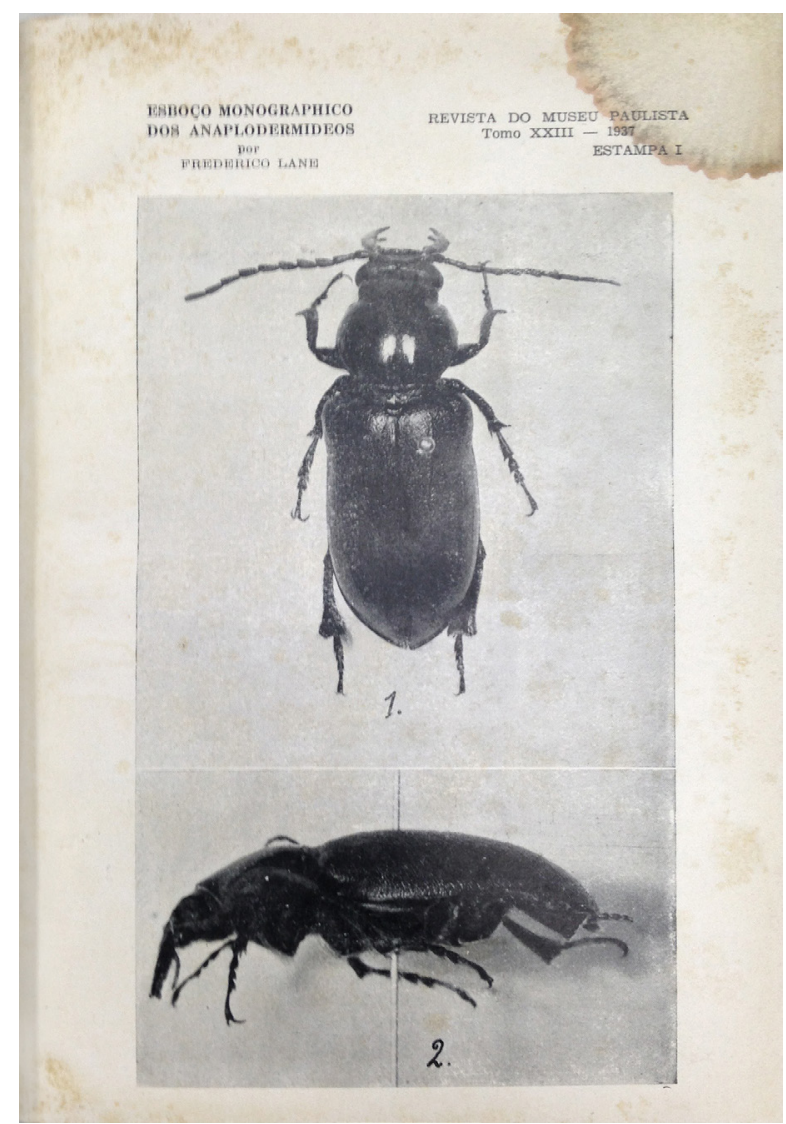

Figura 3 - Esboço Monográfico dos Anaplodermídeos. Fotografia de Frederico Lane. Fonte: Revista do Museu Paulista (1937). 
As fotografias tomadas de topo e de lado de uma espécie de besouro usavam recursos adquiridos para o laboratório fotográfico. Todas as estruturas 67. Lissovsky (1995). biológicas, como mandíbulas, cabeça, abdômen, patas, articulações e carapaça podiam agora ser observadas em detalhe, facilitando os debates e a apreensão dos novos avanços. A microfotografia possibilitada por lentes e adaptações no condensador do ampliador permitia que os naturalistas do museu produzissem imagens que antes requeriam fotógrafos externos, muitas vezes pouco industriados para tais atividades. A fotografia difundida a partir de então poderia ser orientada para os objetivos concretos da instituição, ainda que sua qualidade fosse ainda limitada pelos equipamentos disponíveis. Assim o Museu Paulista reestabelecia, com fortes amarras, um diálogo institucional de nível internacional, pautado por linguagem compartilhada e difundida entre a comunidade científica.

A compra do laboratório fotográfico é episódio de elevado significado para - Museu Paulista. Entre a penúria orçamentária e a manutenção do prestígio internacional, a aquisição de tal equipamento representou uma virada institucional. Não por menos, publicado após a aquisição do laboratório, o tomo 23 da Revista do Museu Paulista é documento eloquente dessa revolução que se equacionou no museu no decorrer da década de 1930. Nesse aspecto vale reforçar uma vez mais que, desde o final do século XIX, as instituições museológicas, em especial, vinham se dedicando à formação de arquivos e coleções fotográficas de qualidade para suprir necessidades institucionais, bem como se posicionar em relação à própria disciplina de história da arte.

Heinrich Wölfflin tratou desse tema em profundidade entre 1896 e 1915 , em três textos dedicados à relação da fotografia com a história da arte ${ }^{66}$ na virada do século XIX para o XX. Tal reflexão serviria de base teórica para o texto "Pequena história da fotografia", de Walter Benjamin, que viria a ter ampla divulgação e impacto sobre a historiografia moderna da fotografia ao longo do século XX, como já destacado por Lissovsky. ${ }^{67}$ Naquele momento, o historiador alemão buscava definir estatutos e protocolos documentais para que os fotógrafos e historiadores da arte pudessem produzir e selecionar boas fotografias para a leitura da tridimensionalidade, volumetrias, texturas, proporções e da própria temática representada pelo objeto. Os artigos publicados por Wölfflin, apesar de sua enorme repercussão no meio científico, foram só recentemente traduzidos para o inglês, pela historiadora Geraldine A. Johnson, ${ }^{68} \circ$ que demonstra $\circ$ interesse contemporâneo por revisitar a história do uso de fotografias pela história da arte. Não por menos, em paralelo às traduções dos textos do historiador alemão, Johnson se ocupa de requalificar, em especial, os arquivos fotográficos em posse de museus e instituições científicas. 
Neste início do século XXI, diversos pesquisadores ligados a museus, universidades e instituições de pesquisa têm se dedicado a revisitar a história de instituições, especialmente do ponto de vista de suas fotografias e arquivos fotográficos. Constanza Caraffa é, sem sombra de dúvidas, uma das pesquisadoras de maior relevância nesse tema, destrinchando os arquivos fotográficos como elementos intrínsecos ao próprio nascimento da história da arte. ${ }^{69}$ Em sentido muito semelhante, os pesquisadores Elizabeth Edwards e Chistopher Morton vêm tratando da importância da fotografia no interior das instituições museológicas não apenas no seu aspecto artístico, mas como documento da própria lógica de produção intelectual das instituições. Segundo eles: "What has so far been lacking is a detailed understanding of these photographs as collections in their own right - how they are formed, and how they are either transformed by their entry into a museum more else how their status might shift over time within their institutional life" . 70 O que está por trás do trabalho de tais historiadoras não é, portanto, uma reflexão calcada apenas no documento fotográfico, mas nas coleções fotográficas como evidências ou registros da própria história institucional das políticas implementadas pelos museus. Do mesmo modo, as coleções e arquivos fotográficos são destacados por esses pesquisadores como elementos essenciais ao entendimento da história intelectual por trás de tais instituições museológicas, dentre as quais o Museu Paulista, presente e atuante nessa rede institucional.

Mas vale notar que o problema colocado ao Museu Paulista se encontra na emergência de uma cultura dos impressos, em que as revistas, cada vez mais fundamentadas em imagens, cumprem um papel decisivo na divulgação dos avanços científicos, assim como na sedimentação do prestígio institucional. A história intelectual da primeira metade do século XX, com reconhecido entendimento e apreensão por parte do Museu Paulista, tem, portanto, relações com a cultura visual daqueles anos. Uma instituição moderna que se pretendia em consonância com o seu tempo não podia dispensar a reflexão em torno da visualidade. $\bigcirc$ Museu Paulista foi partícipe desse processo e lutou bravamente para manter sua posição num acirrado ambiente internacional. 


\section{REFERÊNCIAS}

FONTES MANUSCRITAS

ARQUIVO DA PREFEITURA MUNICIPAL DE SÃO PAULO. Subfundo do Departamento de Cultura. Grupo Doc. História e Social. Processo 12953. São Paulo, 1937. (Administração de Pessoal, caixa 10).

Subfundo do Departamento de Cultura. Grupo Doc. História e Social. Processo 12953. São Paulo, 1938. (Administração de Pessoal, caixa 11).

ARQUIVO DO MUSEU PAULISTA. Relatórios anuais dos exercícios de 1930 a 1939. São Paulo, 1930-1939.TAUNAY, Affonso d'Escragnolle. Cartas trocadas por Affonso d'Escragnolle Taunay entre os anos de 1930 e 1939. São Paulo: Arquivo do Museu Paulista, 1930-1939.

FONTES ICONOGRÁFICAS

STILlE, Paul. Convento de São Francisco em Olinda. São Paulo: Acervo Iconográfico do Museu Paulista, s/d. (Coleção Affonso de Escragnolle Taunay, 1-14146).

Interior da Igreja de São Bento no Rio de Janeiro. São Paulo: Acervo Iconográfico do Museu Paulista, s.d. (Coleção Affonso de Escragnolle Taunay, 1-14196).

Igreja da Ordem Terceira de São Francisco. São Paulo: Acervo Iconográfico do Museu Paulista, s/d. (Coleção Affonso de Escragnolle Taunay, 1-14442).

- Fazenda do Paraíso - Sul de Minas, fronteira com o Estado do Rio. São Paulo: Acervo Iconográfico do Museu Paulista, s/d. (Coleção Affonso de Escragnolle Taunay, 1-14876).

Estátua de Profeta de Autoria de Aleijadinho - Igreja do Bom Jesus de Matozinho. São Paulo: Acervo Iconográfico do Museu Paulista, s/d. (Coleção Affonso de Escragnolle Taunay, 1-14886). 
LIVROS, ARTIGOS E TESES

ANDRADE, Mário de. Cartas de trabalbo: correspondência com Rodrigo Mello Franco de Andrade, 1936-1945. Brasília: SPHAN; Fundação Pró-Memória, 1981.

ANDRADE, Rodrigo Melo Franco de. Rodrigo e o SPHAN. Rio de Janeiro: MinC; SPHAN; PróMemória, 1987.

BENJAMIN, Walter. A obra de arte na era da sua reprodutibilidade técnica. In: Sobre arte, técnica, linguagem e política. Lisboa: Relógio d’Água, 1992. p. 71-110.

BREFE, Ana Cláudia Fonseca; MOREL-DELEDALlE, Myrianne. O Monumento aos Andradas. Santos: Fundação Arquivo e Memória de Santos, 2005.

CARAFFA, Costanza (Ed.). Photo archives and the photographic memory of Art History. Berlin: Deutscher Kunstverlag GmbH, 2011.

CARLINI, Álvaro. Cante lá que gravam cá: Mário de Andrade e a Missão de Pesquisas Folclóricas de 1938. 1994. 190 f. Dissertação (Mestrado em História) - Universidade de São Paulo, São Paulo, 1994.

CARVALHO, Vânia Carneiro de; LIMA, Solange Ferraz de. Fotografia e cidade: da razão à lógica do consumo - Álbuns de São Paulo (1887-1954). Campinas: Mercado de Letras, 1997.

COSTA, Eduardo Augusto. Arquivo, poder, memória: Herman Hugo Graeser e o Arquivo Fotográfico do Iphan. São Paulo: Alameda, 2018.

COSTA, Helouise (Org.). As origens do fotojornalismo no Brasil: um olhar sobre O Cruzeiro. São Paulo: Instituto Moreira Salles, 2012.

COSTA, Helouise. Da fotografia como arte à arte como fotografia: a experiência do Museu de Arte Contemporânea da USP na década de 1970. Anais do Museu Paulista, São Paulo. v. 16, n. 2 , p. 131-173, 2008.

CURY, Isabelle (Org.). Cartas patrimoniais. Brasília: Iphan, 2004.

DECKKER, Zilah Quezado. Brazil Built: the architecture of the modern movement in Brazil. London: Spon; New York: Taylor \& Francis, 2001. 
DUARTE, Benedito Junqueira. B. J. Duarte: caçador de imagens. São Paulo: Cosac \& Naify, 2007.

EDWARDS, Elizabeth; MORTON, Christopher. Between art and information: Towards a collecting history of phographs. In: Photographs, museums, collections: between art and information. London: Bloomsbury, 2015. p. 3-21.

FARIA, Ana Lúcia Goulart de. O direito à infância: Mário de Andrade e os Parques Infantis para as crianças de família operária na cidade de São Paulo. 1994. 250. f. Tese (Doutorado em Educação) - Universidade de São Paulo, São Paulo, 1994.

FONSECA, Brenda Coelho; CERQUEIRA, Telma Soares. Mapeamento preliminar das atividades dos Fotógrafos no IPHAN (1937-1987). In: LIMA, Francisca Helena Barbosa; MELHEM, Mônica Muniz; CUNHA, Oscar Henrique Liveral de Brito (Coord.). A fotografia na preservação do patrimônio cultural: uma abordagem preliminar. Rio de Janeiro: COPEDOC/IPHAN, 2008. p. 13-32. (Cadernos de pesquisa e documentação do Iphan, 4).

FREYRE, Gilberto. Casa Grande e Senzala. São Paulo: Global, 1933.

GOODWIN, Philip L. Brazil Builds: architecture new and old, 1652-1942. Photographs by G. E. Kidder Smith. New York: Museum of Modern Art, 1943.

HOLANDA, Sergio Buarque de. Raízes do Brasil. São Paulo: José Olympio, 1936.

IHERING, Hermann von. Os Botocudos do Rio Doce. Revista do Museu Paulista, São Paulo, v. 8, p. $38-51,1911$.

JOHNSON, Geraldine A. (Un)richtige Aufnahme: Renaissance Sculpture and the visual historiography of Art History. Art History, p. 13-54, fev. 2013.

LACERDA, Aline Lopes de. Fotografia e propaganda política: Capanema e o projeto editorial Obra getuliana. In: GOMES, Ângela de Castro. Capanema: o ministro e seu ministério. Rio de Janeiro: Editora FGV, 2000. p. 103-143.

LISSOVSKY, Mauricio; JAGUARIBE, Beatriz. Imagem fotográfica e imaginário social. Eco-Pos, Rio de Janeiro, v. 9, n. 2, p. 88-109, 2006.

LISSOVSKY, Mauricio. A fotografia e a pequena bistória de Walter Benjamin. 1995. $127 \mathrm{f}$. Dissertação (Mestrado em Comunicação) - Universidade Federal do Rio de Janeiro, Rio de Janeiro, 1995. 
LOBO, Maurício Nunes. Memória e Fotografia: a cidade de Santos nas imagens do fotógrafo José Marques Pereira. Revista Ceciliana, Santos, p. 1-21, maio 2012.

MAUAD, Ana Maria. Fotografia pública e a experiência histórica contemporânea: possibilidades metodológicas. In: SCHIAVINATTO, Iara Lis Franco; COSTA, Eduardo Augusto (Orgs.). Cultura visual e história. São Paulo: Alameda, 2016. p. 173-198.

MENESES, Ulpiano T. Bezerra. Fontes visuais, cultura visual, história visual: balanço provisório, propostas cautelares. Revista Brasileira de História, São Paulo, v. 23, n. 45, p. 11-36, 2003.

NOBRE, Ana Luiza. A eficácia do corte. In: GAUTHEROT, Marcel. O Brasil de Marcel Gautherot. São Paulo: Instituto Moreira Salles, 2001. p. 12-25.

OLIVEIRA, Helena de Salles (Org.). O Museu Paulista e a gestão de Afonso Taunay: escrita da história e historiografia, séculos XIX e XX. São Paulo: Museu Paulista, 2017.

PISO, Guilherme. História Natural do Brasil. São Paulo: Nacional, 1948.

RUBINO, Silvana. As fachadas da história: os antecedentes, a criação e os trabalhos do Serviço do Patrimônio Histórico e Artístico Nacional, 1937-1968. 1991. 206 f. Dissertação (Mestrado em Antropologia) - Universidade Estadual de Campinas, Campinas, 1991.

TAUNAY, Affonso de Esgragnolle. Monumento comemorativo da Independência do Brasil em glorificação aos irmãos Andradas: memorial descriptivo do projecto da Companhia Construtora de Santos. São Paulo: Comissão Executiva do Monumento à Independência e aos Andradas, 1920.

WÖLFFLIN, Heinrich. How one should photograph Sculpture. Art History, p. 53-71, fev. 2013.

Artigo apresentado em 04/04/2018. Aprovado em 12/09/2018.

\section{(cc) BY}

